\title{
Bovine freeze-dried blood as alternative for feeding of screwworm larvae
}

\author{
Sangre liofilizada bovina como alternativa para la alimentación \\ de larvas del gusano barrenador del ganado \\ Diego Medina-Arellano* \\ Programa Centroamericano de Maestría en Entomología, Universidad de Panamá, Panamá
}

*Autor al que se dirige la correspondencia:iddiego1989@hotmail.com

Recibido: 16 de mayo 2019 / Revisión: 19 de septiembre 2019 / Aceptado: 07 de octubre 2019

\begin{abstract}
$\mathrm{T}$ The myiasis caused by Cochliomyia hominivorax (Coquerel) or screwworm is considered one of the most traumatic and relevant to the region due to its economic implications and its importance in public health. The purpose of this study was to compare the reproductive and developmental indexes of screwworm using citrated and freeze-dried bovine blood, spray-dried bovine blood (currently used by Panama-United States Commission for the Eradication and Prevention of Screwworm -acronym in spanish [Copeg]) and bovine citrated liquid blood. The use of freeze-dried arises through the premise that, due to its process of elaboration constitutes an alternative of better quality for the feeding of the screwworm in function of the integrity of sanguine proteins during its processing. For the comparison of the different diets, the following parameters were used: $\mathrm{pH}$, total pupae weight, pupae size, total pupae volume, emergency percentage, oviposition percentage and hatching percentage. In the case of freeze-dried blood, it showed better mean (standard deviation) indexes of emergence, 83.42 (11.45), and 73.11 (15.97) ( $p=.01)$; and hatching, 89.70 (8.88), and 84.08 (8.29), ( $p=.004)$ compared to the diet based on spray-dried blood. By virtue of the above, freeze-dried blood proved to be a source of protein with potential to develop insect breeding programs.
\end{abstract}

Keywords: Cochliomyia hominivorax, insects rearing, reproductive and developmental indexes, larval diet.

\section{Resumen}

$\mathrm{L}$ a miasis causada por Cochliomyia hominivorax (Coquerel) o gusano barrenador del ganado (GBG) es considerada una de las más traumáticas y relevantes para la región debido a sus implicaciones económicas y su importancia en la salud pública. El propósito de este estudio fue comparar los índices reproductivos y de desarrollo del GBG con sangre bovina liofilizada citratada, sangre bovina secada por pulverización (actualmente utilizada por la Comisión Panamá-Estados Unidos para la Erradicación y Prevención del Gusano Barrenador del Ganado [Copeg]) y sangre líquida bovina citrata. El uso de liofilizado surge bajo la premisa de que, debido a su proceso de elaboración, constituye una alternativa de mejor calidad para la alimentación del GBG en función de la integridad de las proteínas sanguíneas durante su procesamiento. Para la comparación de las diferentes dietas, se utilizaron los siguientes parámetros: $\mathrm{pH}$, peso total de las pupas, tamaño de pupas, volumen total de pupas, porcentaje de emergencia, porcentaje de oviposición y porcentaje de eclosión. En el caso de la sangre liofilizada, mostró mejores promedios (desviación estándar) de índices de emergencia, 83.42 (11.45) y 73.11 (15.97) ( $p=.01)$, y eclosión, $89.70(8.88)$ y $84.08(8.29)(p=.004)$ en comparación con la dieta basada en sangre secada por pulverización. En virtud de lo anterior, la sangre bovina liofilizada demostró ser una fuente de proteína con potencial para desarrollar programas de crianza de insectos.

Palabras claves: Cochliomyia hominivorax, crianza de insectos, índices reproductivos y de desarrollo, dieta larvaria. 


\section{Introduction}

The myiasis caused by Cochliomyia hominivorax (Coquerel) or screwworm is considered one of the most traumatic and relevant to the region, due to its economic impact due to treatment costs, inspections and daily management in livestock farms (Pitti et al., 2011). On the other hand, the reduction in livestock production and mortality has direct effects on food security in the region, as well as implications for public health (Vargas-Terán, Hofmann, \& Tweddle, 2005). Due to these factors, during the 1950 decade several studies were carried out that led to the development of the sterile insect technique, through the populations of this parasite were eradicated from wide geographical areas, avoiding economic losses of approximately USD $\$ 300$ million only in the state of Texas and USD $\$ 588$ million in Central America (Wyss \& Galvin, 1996). In the other hand, Grisi and others, (2014) reported losses caused by C. hominivorax that ascends to USD $\$ 0.34$ billion each year in Brazil related to cattle productivity.

Since 2006 the Commission for the Eradication and Prevention of Screwworms (Copeg) is the institution in charge of producing and dispersing sterile flies, activities that together with epidemiological surveillance guarantee the maintenance of the permanent biological barrier to prevent this parasite. Currently, Copeg uses bovine whole blood powder, dehydrated hen whole egg and dehydrated soy milk for the feeding of screwworm larvae (Chaudhury, Chen, Sagel, \& Skoda, 2015) combined with cellulose fiber that fulfills function of breeding medium (Chaudhury \& Skoda, 2007). This combination provides a suitable environment for the development of individuals. However, the supply of powdered bovine blood due to the high cost and irregularity to obtain it, is one of the problems of the institution (Chaudhury et al., 2015).

In the screwworm breeding program, larval feeding is the most represented in operating costs (Mastrangelo, Bezerra, \& Fernandes 2014). The inputs used to develop the screwworm larvae diet constitute a cost of USD\$0.19-0.22 per 1,000 larvae produced. Therefore, the development of practical, effective and economic diets conforms a constant target (Forero, Cortés, \& Vilamil, 2007). Low-cost and locally available protein provides a solution for formulating diets at lower costs (Chen, Chaudhury, Sagel, Phillips, \& Skoda, 2014).

Additionally, the use of powdered and dehydrated blood at high temperatures $\left(\sim 175^{\circ} \mathrm{C}\right)$-spray drying(currently used by Copeg) decreases the nutritive value of plasma proteins (Delaney, 1975) due to the damage of their covalent bonds when exposed to temperatures higher than $100^{\circ} \mathrm{C}$ (Somero, 1995).

According to U.S. Patent No. 5,690,963 (1997), the term lyophilization -freeze-drying- corresponds to the freezing of a substance, then to reduce the concentration of one of the solvents through sublimation, desorption, and vacuum. Lyophilization is a potential approach for the preservation of blood cells in the long term (Yu et al., 2004), since this process prevents chemical and morphological changes in erythrocytes, specifically in the surface-volume range, internal viscosity and membrane rigidity (Han et al., 2005; Scott, Lecak, \& Acker, 2005; Sowewimo-Coker, Goodrich, Zerez, \& Tanaka, 1993). On the other hand, the viability for its subsequent storage is given by maintaining the integrity of the blood for ten months at room temperature, while its reconstitution with water provides a stability of two weeks (Subramanian, Mérangerm, \& Connor, 1985; Yu et al., 2004).

The search for alternatives for the inputs used in formulating specialized diets in insect eradication programs is a constant activity and does not only mean achieving the efficiency of their activities, but also constitutes the sustainability of the projects and the development of specimens with better physical and reproductive characteristics compared to their competitors in the field. Therefore, this study consisted of evaluating bovine freeze-dried blood as an alternative for feeding screwworm larvae and determining its impact on the reproductive and development indexes of this insect.

Given the circumstances, this study aims to evaluate freeze-dried blood as a substitute for the preparation of screwworm larvae diets comparing it with spray dried blood and fresh blood. Freeze-dried blood constitutes a local and available raw material. In addition the lyophilized process guarantees that the blood components do not undergo morphological/chemical changes. Therefore, the ingested protein is of higher quality, translating into obtaining better developmental and reproductive indexes for the screwworm breeding program.

\section{Materials and methods}

\section{Dietary ingredients and insects}

Fresh bovine blood was obtained from a local abattoir and mixed with sodium citrate (Sigma-Aldrich; 4 g/100 ml of blood) (Chaudhury, Skoda, \& Sa- 
gel, 2011). Spray-dried whole bovine blood and spraydried poultry eggs were purchased from the California Spray Dry Co. (Stockton, CA), and powdered milk was from the Calva Products Inc. (Acampo, CA). Tests were conducted on the Panama-J06 strain of screwworm developed from screwworm flies collected from Jamaica in 2006. This study was conducted at the Agricultural Research Service (ARS) facilities (BSL-3) of Copeg, located in the community of Pacora, Panama.

The freeze-drying process was carried out using citrated bovine blood (Chaudhury et al., 2011) and frozen at $-20^{\circ} \mathrm{C}$ (Quan et al., 2004), in a lyophilizer Labconco ${ }^{\circledR}$ model 7750020 , where a temperature of $-45^{\circ} \mathrm{C}$ (Han et al., 2005) and a pressure of $0.77 \mathrm{mbar}$ were constant (U.S. Patent No. 5,690,963, 1997). With regard to lyophilized time, it took $48 \mathrm{~h}$ non-continuous to process batches of $\sim 2 \mathrm{~kg}$, having a loss of $\sim 72 \%$ of the total volume, similar as presented by Rindler, Lüneberger, Schwindke, Heschel, and Rau (1999).

\section{Preparation of diets}

Three diets were tested using a different type of bovine processed blood. The standard rearing medium (Production Diet) served as Control 1, which was prepared by mixing cellulose fiber (5.25\%) (Chaudhury \& Skoda, 2007), spray dried blood (4.5\%), spray-dried poultry eggs $(5.0 \%)$, powdered milk (4.5\%), formaldehyde $(0.10 \%)$ (Sagel, Phillips, Chaudhury, \& Skoda, $2015)$ and hot water $(80.65 \%)$. The ARS Diet (Control 2) consisted in cellulose fiber (5.25\%), fresh and citrated liquid bovine blood (16.0\%), spray-dried poultry eggs $(5.0 \%)$, powdered milk (4.5\%), formaldehyde $(0.10 \%)$ and hot water $(69.15 \%)$. Freeze-dried blood diet was prepared using cellulose fiber (5.25\%), citrated freezedried blood (4.5\%), spray-dried poultry eggs $(5.0 \%)$, powdered milk ( $4.5 \%)$, formaldehyde $(0.10 \%)$ and hot water $(80.65 \%)$.

\section{Comparison of diets}

Three trays per each type of diet were settled (nine in total) and four replicates were performed. Each larval rearing tray (capacity $1.6 \mathrm{l}$ ) received $75 \mathrm{mg}$ of eggs ( 1,500 eggs) placed on a 2 x $2 \mathrm{~cm}$ moist paper towel on top of $100 \mathrm{ml}$ of diet. Each time new diet was added, $\mathrm{pH}$ was measured. The tray remained closed with hole cap and incubated at $41^{\circ} \mathrm{C}$ and $80 \%$ relative humidity (RH). After $24 \mathrm{~h}$, the trays were transferred to another room $\left(37^{\circ} \mathrm{C}\right.$ and $\left.55 \% \mathrm{RH}\right)$. After $48 \mathrm{~h}$ since the incubation (Day 3), $300 \mathrm{ml}$ of diet were added on the tray, which was left half open. In day 4, $800 \mathrm{ml}$ of new diet were added over the old one. The trays were removed and a new rotation of room was performed $\left(31^{\circ} \mathrm{C}\right.$ and $60 \% \mathrm{RH}$ ). The trays remained in the growth room for $96 \mathrm{~h}$, in order to initiate the descent and pupation of larvae over $1.27 \mathrm{~cm}$ of sawdust.

\section{Recording of life-history parameters}

After six days since incubation, pupal sifting was carried out in order to obtain biological performance values of the reared larvae. Data of the following parameters were recorded: Total volume of pupae obtained per tray, total weight of pupae obtained per tray, number of pupae in $25 \mathrm{ml}$ of the total collected and weight of pupae in $25 \mathrm{ml}$ of the total collected. The last two parameters served as the basis for calculating the size of the individuals collected (Chaudhury et al., 2015). To determine emergency, four little cups with hole cap, sawdust and 100 pupae were placed for each diet tray (12 in total). To determine fecundity, nine cages for each diet type (27 in total) containing little cups with sawdust and $25 \mathrm{mg}$ of pupae were settled. During the 16th day, distilled water and diet for adults in sufficient quantity were placed in these cages. The adult diet consisted of $225 \mathrm{~g}$ spray-dried poultry egg, 1,800 g of sugar, $45 \mathrm{~g}$ of carrageenan and 2,430 $\mathrm{ml}$ of water. At seven days old, a device was placed for oviposition of females, consisting of a plastic container with lid containing hot water, on which were placed approximately $3 \mathrm{~g}$ of bovine ground meat with attractive liquid (Chaudhury, Sagel, \& Skoda, 2012). Later the cages were taken to a dark area for $3 \mathrm{~h}$ to facilitate oviposition. To determine hatching, in a Petri dish with black filter paper and paper towels moistened with distilled water, 100 eggs from each cage were aligned to determine the hatch rate at a temperature of $38^{\circ} \mathrm{C}$ for $24 \mathrm{~h}$. Prior to the alignment of the eggs, they were separated from the queresa using $4 \%$ potassium hydroxide (Berkebile \& Skoda, 2002) for $2 \mathrm{~min}$ in a test tube. Only a single generation was analyzed in each replica.

Statistical analysis (Kruskal-Wallis test $p<.05$ and post-hoc Dunn test $p<.05$ ) was realized using the software R (v.3.6.1) with "Dunn.test” package (v.1.3.5). 


\section{Results}

For the comparison of three different screwworm larvae diets, the following parameters were used: $\mathrm{pH}$, total pupae weight, pupae size, total pupae volume, emergency percentage, oviposition percentage and hatching percentage. Three trays per each type of diet were settled (nine in total) and four replicates were realized. To determine difference between treatments, Kruskal-Wallis test was realized at a significant level of $p>.05$.

The results obtained (Table 1) and Kruskal-Wallis test, demonstrated the weight, volume and size of the pupae were not significantly different between the treatments $(p>.05)$.

According the Kruskal-Wallis test, there is a difference $(p=.01)$ in the emergency percentage. ARS control diet and freeze-dried blood were not significantly different $(p=.166)$. Also, production diet and the ARS control diet were not significantly different ( $p$ $=.097)$. Finally, the test indicates that there is also a difference between the production diet and the freezedried blood-based diet $(p=.002)$.

In relation to the oviposition data, Kruskal-Wallis test indicates differences between treatments $(p=.03)$, where freeze-dried diet has higher number of eggs lai in comparison with ARS Diet, according to Table 1 and Dunn Test $(p=.011)$. Production diet and the ARS control diet were not significantly different $(p=.046)$.

Regarding hatching, ARS control diet and Freezedried blood-based diet were not significantly different $(p=.14)$. Likewise, were not significantly different between Production diet and ARS control diet $(p=.075)$. On the other hand, Production diet and Freeze-dried blood diet were significantly different $(p=.001)$.

Related to $\mathrm{pH}$ data, there is a difference $(p=.001)$ between treatments. ARS control diet and Freeze-dried Diet were not significantly different $(p=.98)$. On the other hand, Production diet was significantly different to ARS diet $(p=.001)$ and Freeze-dried blood diet $(p$ $=.001$ ).

\section{Discussion}

It is important to consider that the analysis made refer to the number of pupae obtained, but not to the total of individuals present (pupae and larvae). Hightower, Spates, and García (1971) point out that the critical stage for pupating of screwworm is reached when it has grown about $50 \%$ of its potential weight. Observations made during the study showed that insects fed

Table 1

Biological parameters of screwworm reared on diets using spray-dried blood (Control 1), fresh bovine blood (Control 2) and freeze-dried blood

$\begin{array}{cccccccc}\text { Treatments } & \text { Pupal } & \text { Pupal wt } & \text { Size }(\mathrm{mg}) & \begin{array}{c}\text { Adult } \\ \text { emergence }(\%)\end{array} & \begin{array}{c}\text { Oviposition } \\ (\mathrm{mg})\end{array} & \text { Hatching }(\%) & \mathrm{pH}\end{array}$
Production
Diet (Control 1$)$
$222(30)$
$207(51.7)^{\mathrm{a}}$
$64.5(1.8)^{\mathrm{a}} 73.11(15.97)$
$513(391.66)^{\mathrm{ab}} \quad 84.08(8.29)^{\mathrm{b}}$
$7.43(0.824)^{b}$
ARS Diet
(Control 2)
$207(51.7)^{\mathrm{a}} 96(22.6)^{\mathrm{a}}$
$68.8(3.1)^{\mathrm{a}} \quad 81.14(9.46)^{\mathrm{ab}}$
$423(314.53)^{a}$
$88.66(4.55)^{\mathrm{ab}}$
$6.72(0.697)^{\mathrm{a}}$
Freeze-dried
blood Diet
$200(45.1)^{\mathrm{a}} 97(18.8)^{\mathrm{a}}$
$69.1(4.9)^{\mathrm{a}} 83.42(11.45)^{\mathrm{bc}} 668(298.48)^{\mathrm{bc}}$
$89.70(8.88)^{\mathrm{ac}}$
$6.75(0.673)^{a}$

Note: Means under the same parameter of the diets not followed by the same letter were significantly different from each other based on Dunn's Test $(p<.05)$. 
the Freeze-dried blood based diet (as this raw material from small and non-homogeneous lots) showed heterogeneity during larval development (different larval stages). The number of pupae present was lower in comparison to the rest; however, the size of the pupae of the group fed with Freeze-dried blood was observed within the range acceptable for desired quality effects. The mean of all treatments is above the minimum limit recommended by Hightower, Spates, and García (1972) of $60.5 \mathrm{mg}$.

Although the results of the statistical analysis in relation to pupal size does not reflect differences, there is a trend in which the Freeze-dried blood based diet presents higher values in comparison to the rest, which is congruent with Spates and Hightower (1970), who indicate that differences in size and weight may be due to increased feeding time in the larval stage.

According to Gingrich, Graham, and Hightower (1971), there is a direct correlation between larval weight and adult size. Pastor, Cicková, Martínez-Sánchez, Takác, and Rojo (2011) point out that the potential of fecundity and body size in insects are intrinsically related, where large females oviposit more compared to smaller ones. The authors refer that, to greater abdominal space, consequently more ovarioles and eggs produced. In relation to the results obtained, the high egg production is strongly influenced by several factors, one of them being a high-quality protein-based diet, which is congruent with that presented by Spradbery and Sands (1981), who suggest that in the case of Chrysomya bezziana, the amount of fat body acts as a reservoir of protein, which directly affects the maturation of the ovaries. Likewise, Sagel, Berkebile, Foster, and Skoda (2002) refer that the amino acids contained in the blood have positive effects on the ogenesis of $C$. hominivorax. These statements could be related to the larvae fed with Freeze-dried blood, since when they had larger size due to the greater amount of protein in diet (and of better quality), they obtained better indexes.

On the other hand, larger males have an advantage over smaller males competing for wild females (Alley \& Hightower, 1966; Pitti et al., 2011), which is important to consider in insect eradication programs (Ekanayake, Clarke, \& Schutze, 2017). For example, in the case of Phormia regina, larger males are capable to mate with a wider size variety of females and inseminate them successfully, which suggests a larger body and therefore a larger aedeagi, has reproductive advantages in comparison with smaller males (Stoffolano et al., 2000).
With regard to pupal weight, the percentage of survival and fecundity are parameters mainly affected by the concentration of milk, egg and blood (Brown \& Snow, 1979; Taylor, 1988), being the last one critical in larval development, since concentrations greater than $12 \%$ have a negative effect and decrease the amount of individuals produced due to the activity of some enzymes, such as: lipases, liposomes, oxygenases, proteases, catalases and peroxidases that may have adverse effects on the diet (Cohen, 2015), which could be related to the low oviposition index obtained by the ARS control diet. Chaudhury and others, (2011) suggest that developmental problems in the larval or pupal stage possibly involve synthesis, release, or both of ecdysteroids in larvae feed with citrated liquid bovine blood, that could have lower egg weight due low pupal weight.

According with the results of this study, the use of non-traditional blood sources for feeding larvae of C. hominivorax has demonstrated its viability in terms of developmental and reproductive parameters. In the case of Freeze-dried blood, it has demonstrated better indexes of size, emergence and hatching compared to the diet based on spray-dried blood. According to this results, the use of Freeze-dried has potential to insect breeding programs, due to characteristics in its procedure that no constitutes physical or chemical changes in raw materials.

\section{Acknowledgments}

Thanks to all team of ARS-Copeg, specially Agustín Sagel, Nicolás, Domitildo and Rodolfo. Thanks to German Academic Exchange Service (DAAD) for the opportunity to elaborate this research.

\section{References}

Alley, D. A., \& Hightower, B. G. (1966). Mating behavior of the screw-worm fly as affected by differences in strain and size. Journal of Economic Entomology, 59(6), 1499-1502. doi:10.1093/ jee/59.6.1499

Berkebile, D. R., \& Skoda, S. (2002). Chemicals useful for separating egg masses of the screworm. SouthWestern Entomologist Scientific Note, 27(3/4), 297-299.

Brown, H. E., \& Snow, J. W. (1979). Screwworms (Diptera: Calliphoridae): A new liquid medium for rearing screwworm larvae. Journal of Medi- 
cal Entomology, 16(1), 29-32. doi:10.1093/jmedent/16.1.29

Chaudhury, M. F., Chen, H., Sagel, A., \& Skoda, S. R. (2015). Effects of new dietary ingredients used in artificial diet for screwworm larvae (Diptera: $\mathrm{Ca}$ lliphoridae). Journal of Economic Entomology, 108(3), 1429-1434. doi:0.1093/jee/tov039

Chaudhury, M. F., Sagel, A., \& Skoda, S. R. (2012). Evaluation of artificial larval rearing media waste as oviposition attractant for new world screwworms (Diptera: Calliphoridae). Journal of Medical Entomology, 49(2), 293-298. doi:10.1603/ ME11194

Chaudhury, M. F., \& Skoda, S. R. (2007). A cellulose fiber-based diet for screwworm (Diptera: Calliphoridae) larvae. Journal of Economic Entomology, 100(1), 241-245. doi:10.1093/jee/100.1.241

Chaudhury, M. F., Skoda, S. R., \& Sagel, A. (2011). Solidifying agent and processing of blood used for the larval diet affect screwworm (Diptera: Calliphoridae) life-history parameters. Journal of Economic Entomology, 104(3), 1103-1107. doi:10.1603/ec10375

Chen, H., Chaudhury, M. F., Sagel, A., Phillips. P. L., \& Skoda, S. R. (2014). Artificial diets used in mass production of the New World screwworm, Cochliomyia hominivorax. Journal of Applied Entomology, 708-714. doi:10.1111/jen.12112

Cohen, A. C. (2015). Insects Diets: Science and Technology $\left(2^{\text {nd }}\right.$ ed.). Boca Raton, USA: Taylor \& Francis Group.

Ekanayake, E.W.M.T.D. Clarke, A. R., \& Schutze, M. K. (2017). Effect of body size, age, and premating expierence on male mating in Bactrocera tryoni (Diptera: Tephritidae). Journal of Economic Entomology, 110(5), 2278-2281. doi:10.1093/jee/ tox 186 .

Forero, E. G., Cortés, J. A., \& Vilamil, L. C. (2007). Ecología y epidemiología del gusano barrenador del ganado, Cochliomyia hominivorax (Coquerel, 1858). Revista de Medicina Veterinaria, 14, 3749. doi:10.19052/mv.1800

Gingrich, R. E., Graham, A. J., \& Hightower, B. G. (1971). Media containing liquefied nutrients for mass-rearing larvae of the screw-worm. Journal of Economic Entomology, 64(3), 678-683. doi:10.1093/jee/64.3.678
Grisi, L., Leite, R. C., Martins, J. R. S., Barros, A. T. M., Andreotti, R., Duarte, P. H., ... \& Villela, H. S. (2014). Reassessment of the potential economic impact of cattle parasites in Brazil. Revista Brasileira de Parasitologia Veterinária, 23(2), 150-156. doi:10.1590/S1984-29612014042

Han, Y., Quan, G. B., Liu, X. Z., Ma, E. P., Liu, A., Jin, P., \& Cao, W. (2005). Improved preservation of human red blood cells by lyophilization. Cryobiology, 51, 152-164. doi:10.1016/j.cryobiol.2005.06.002

Hightower, B. G., Spates, G. E., \& García, J. J. (1971). Growth and critical size at pupation for larvae of the screwworm developing in fresh wounds. Journal of Economic Entomology, 65(5), 13491352. doi:10.1093/jee/65.5.1349

Hightower, B. G., Spates, G. E., \& García, J. J. (1972). Relationship between weight of mature larvae, size of adults, and mating capability in medium-reared male screwworms. Journal of Economic Entomology, 65(5), 1527-1528. doi:10.1093/ jee/65.5.1527

Mastrangelo, T., Bezerra, F., \& Fernandes, T. (2014). Dietas larvais alternativas para criação massal da mosca da bicheira, Cochliomyia hominivorax. Ciência Rural, 44(4), 672-677. doi:10.1590/ S0103-84782014000400016.

Quan, G. B., Han, Y., Liu, X.-Z., Ma, E.-P., Liu, A., Jin, P., \& Cao, W. (2004). Effect of pre-freezing temperature and lyophilizer shelf temperatur on recovery of red blood cells after lyophilization. Journal of Experimental Hematology, 12(3), 368-371.

Pastor, B., Cicková, H., Martínez-Sánchez, A., Takác, P., \& Rojo, S. (2011). Effect of the size of the pupae, adult diet, oviposition substrate and adult population density on egg production in Musca domestica (Diptera: Muscidae). European Journal of Entomology, 108. 587-596.

Pitti, A., Skoda, S. R., Kneeland, K .M., Berkebile, D. R., Molina-Ochoa, J., Chaudhury, M. F., ... Fosterm J. E. (2011).Effect of adult screworm male size on mating competence. Southwestern Entomologist, 36(1), 47-60. doi:10.3958/059.036.0105 Rindler, V., Lüneberger, S., Schwindke, P., Heschel, I., \& Rau, G. (1999). Freeze-drying of red blood 
cells at ultra-low temperatures. Cryobiology, 38 . 2-15. doi:10.1006/cryo.1998.2143

Delaney R. A. M. (1974). The nutritive value of porcine blood plasma concentrates prepared by ultrafiltration and spray drying. Journal of the Science of Food and Agriculture, 26(3). 303-310. doi: 10.1002/jsfa.2740260310

Sagel, A., Berkebile, D. R., Foster, J. E., \& Skoda, S. R. (2002). The optimum diet of spray-dried animal blood cells as protein source for adult screwworms (Diptera: Calliphoridae). Journal of Entomological Science, 37(4), 353-362.

Sagel, A., Phillips, P., Chaudhury, M., \& Skoda, S. (2015). Managing ammonia emissions from screwworm larval rearing media. Journal of Economic Entomology, 109(1), 478-483. doi:10.1093/ jee/tov291

Scott, K. L., Lecak, J., \& Acker, J. P. (2005). Biopreservation of red blood cells: Past, present, and future. Transfusion Medicine Review, 19(2), 127-142.

Somero, G. N. (1995). Proteins and emperature. Annual Review of Physiology, 57. 43-68. doi:10.1146/ annurev.ph.57.030195.000355

Sowewimo-Coker, S. O., Goodrich, R. P., Zerez, C. R., \& Tanaka, K. R. (1993). Refrigerated storage of lyophilized and rehydrated, lyophilized human red cells. Transfussion, 33(4), 322-329.

Spargo, B. J., Rudolph, A. S., Chang, B. S., \& Thomas, R. G. I. (1997). US Patent No. 5,690,963. Washington, DC: US Patent and Trademark Office.

Spates, G. E., \& Hightower, B. G. (1970). Variations in the size and reproductive capacity of wildtype and laboratory-adapted populations of the screw-worm fly. Journal of Economic Entomology, 63(5), 1381-1385. doi:10.1093/jee/63.5.1381

Spradbery, J. P., \& Sands, D. P. A. (1981). Larval fat body and it's relationship to protein storage and ovarian develpment in adults of the screw-worm Chrysomya bezziana. Entomologia Experimentalis et Applicata, 30(2), 116-122. doi:10.1111/j.1570-7458.1981.tb03084.x

Stoffolano, J. G., Gonzalez, E. Y., Sanchez, M., Kane, J., Velázquez, K., Oquendo., A. L., ... \& Yin, C. M. (2000). Relationship between size and mating success in the blow fly Phormia regina (Diptera: Calliphoridae). Annals of the Entomological So- ciety of America, 93(3), 673-677. doi:10.1603/ 0013-8746(2000)093[0673:RBSAMS]2.0.CO;2

Subramanian, K. S., Mérangerm, J. C., \& Connor, J. (1985). Hemolyzed, lyophilized bovine blood for quality control of lead determination of human whole blood. Bulletin of Enviromental Contamination and Toxicology, 35(1), 380-385. doi:10.1007/BF01636526

Taylor, D. B. (1988). Response of screwworms (diptera: calliphoridae) to changes in the concentration of blood, egg, and milk in the larval diet. Journal of Economic Entomology, 81(2), 562-567. doi:10.1093/jee/81.2.562

Vargas-Terán, M., Hofmann, H. C., \& Tweddle, N. E. (2005). Impact of screwworm eradication programmes using the sterile insect technique. In V. A. Hendrichs J. \& A. Robinson (Eds.), Sterile Insect Technique (pp. 629-650). Ciudad: Springer.

Wyss, J. H., \& Galvin, T. J. (1996). Central America Regional Screwworm Eradication Program (Benefit/Cost Study). Annals of The New York Academy of Sciences, 791(1), 241-247. doi:10.1111/j.1749-6632.1996.tb53531.X

Yu, J., Liu, J. H., Pu, L. L.-Q., Cui, X., Wang, C., Ouyang, S. L., \& Gao, D. (2004). Freeze-drying of human red blood cells: Influence of carbohydrates and their concentrations. Cell Preservation Technology, 2(4), 270-275. doi:10.1089/ cpt.2004.2.270 